\title{
High Terrestrial Radiation Level in an Active Tin-Mine at Jos South, Nigeria
}

\section{${ }^{1}$ ATIPO, M; ${ }^{2}$ OLARINOYE, $0 ;{ }^{2}$ AWOJOYOGBE, B; ${ }^{2} \mathrm{KOLO}, \mathrm{M}$}

\author{
${ }^{1}$ Nigeria Nuclear Regulatory Authority, Abuja, Nigeria \\ ${ }^{* 2}$ Department of Physics, Federal University of Technology, Minna, Nigeria \\ *Corresponding Author Email: leke.olarinoye@futminna.edu.ng
}

\begin{abstract}
Mineral mining and milling can be a source of national economic and technological development. However, mining of minerals has been confirmed to disturb the natural distribution of radioisotopes in the soil, air and water bodies in the biota. In an attempt to evaluate the radiological burden resulting from tin mining activities at Rayfield-Du area of Jos, the background gamma-radiation level in the mine was measured via a well calibrated hand-held dosimeter placed at $1 \mathrm{~m}$ above ground level. The mean absorbed dose rate, annual effective dose rate and excess lifetime cancer risk for the mine was $0.83 \mu \mathrm{Svh}^{-1} ; 1.44 \mathrm{mSv}^{-1}$ and 0.005 respectively. Generally, dose rates were higher in the mine pits and processing areas as compared to administrative areas of the mine. The mean measured dose rate and calculated dose parameters for the mine were all high when compared to the regulatory limit for public exposure. The potential of developing radiation-induced health defects as a result of high radiation absorbed dose rate by the miners and dwellers around the mine is highly probable.
\end{abstract}

DOI: https://dx.doi.org/10.4314/jasem.v24i3.6

Copyright: Copyright $($ C) 2020 Atipo et al. This is an open access article distributed under the Creative Commons Attribution License (CCL), which permits unrestricted use, distribution, and reproduction in any medium, provided the original work is properly cited.

Dates: Received: 16 November 2019; Revised: 11 January 2020; Accepted: 22 February 2020

Keywords: Gamma-radiation; mine; absorbed dose rate; radiation exposure.

Mining of minerals of any kind contributes negatively to the environment. Although the economic benefits (such as employment opportunity for the populace and revenue generation for the government and local community) accruing from mining could be encouraging, the long term ecological, health and social degradation caused by unregulated and indiscriminate mineral mining and milling activities could lead to quite invaluable economic losses that may eventually dwarf the initial gains. The mineral survey carried out in northern Nigeria between 1904 and 1909 revealed the abundance of tin ore over a wide area of modern-day Jos, Plateau State of Nigeria. Ever since then, more cassiterite and columbite have been discovered (Masok et al., 2015). Consequently, mining activities have been going on in Jos and environs for more than a century (Masok et al., 2015). Unfortunately, the mining processes come with accompanying inevitable environmental damage and hazards (UNSCEAR, 2000; Ademola, 2008; Ibeanu, 2003; Arogunjo et al., 2009; Jibiri et al., 2007). Furthermore, tailings rich in monazite, thorite, and other materials contain heavy and radioactive metals are dumped indiscriminately in and around most mining sites. The presence of Naturally Occurring Radioactive Materials (NORM) such as ${ }^{238} \mathrm{U},{ }^{232} \mathrm{Th}$ and ${ }^{40} \mathrm{~K}$ in ores and in processed waste (tailings) during mining, milling, and processing of NORM bearing minerals has long been established
(UNSCEAR, 2000; Arogunjo et al., 2009). Mining of minerals thus leads to the enhancement in the distribution of NORM and consequently, an elevation in background ionizing radiation emanating from them in soil, water and air around mining fields (Ademola, 2008; Jibiri et al., 2007; Olise et al., 2014). From a radiological protection perspective, the biota and the health of mine workers and the general public who live within the vicinity of mines are of major concern. The indiscriminate dumping of mine tailings (in heaps) which are usually high in background ionizing radiation, present a source of chemical and radiological pollution to man and his environment. The heaps of dumped tailings could be weathered and transported over long distances via weather agents such as wind and surface run-off to inhabited areas, farmlands, and surface water. Thus the elevated background radiation is spread far from the source. In 2007, Jibiri et al. established that many food items grown near mining area contained radium - a radioactive nuclide. Also, research conducted and concluded in 2014 by Olise et al. around tin mining dumpsites in Rayfield area of Jos suggested high values in the concentrations ${ }^{226} \mathrm{Ra},{ }^{232} \mathrm{Th}$ and ${ }^{40} \mathrm{~K}$ and associated radiological parameters in the soils of the dumpsites. Similarly, elevated levels have been reported by many other previous research conducted on Jos and its environs (Ademola, 2008; Ibeanu, 2003; Arogunjo et al., 2009; Jibiri et al., 2007; Olise et al., 
2014; Jwanbot et al., 2012; Usikalu et al, 2011). Most of these studies do not however, give the coordinate and exact location parameters of the studied areas. This has made it very difficult for government, regulatory agencies and researchers to independently verify these findings and perhaps initiate a process of reclamation, rehabilitation and imposing regulations on the mine and its environment. Also, because of ecological and health concerns, the unregulated mining activities in Jos south have made a continuous radiological impact and risk assessment of the mining activities on the miners, public and environment very important and thus the need for this study. This research was aimed to use measured in-situ gammaradiation dose rate and associated radiological risk parameters to delineate areas of high radiation dose in the mining site in Du district area of Jos South, Plateau state, Nigeria.

\section{MATERIALS AND METHOD}

Description of the Study Area: The area known as Jos is the capital of the north-central state of Plateau in Nigeria. The area is bounded by latitudes $9^{\circ} 30^{\prime}$ and $10^{\circ} 10^{\prime} \mathrm{N}$ and longitudes $8^{\circ} 15^{\prime}$ and $9^{\circ} 15^{\prime} \mathrm{E}$ and about 4062 feet above sea level. Climatically, it is dominated by tropical dry and wet conditions with annual rainfall and temperature ranging between $1500-2000 \mathrm{~mm}$ and $20^{\circ} \mathrm{C}-25^{\circ} \mathrm{C}$ respectively (Wapwera et al., 2005). The topography is characterized by series of highlands of variable heights and flat topography. Also, the vegetation consists of stunted trees, tall grasses and, shrubs.

The geology of Jos shown in Figure 1(NGSA, 1963) is in the north-central basement complex of Nigeria containing plutonic and volcanic rock types. These rocks are classified into: younger granites, Precambrian rocks and intrusive older granites (migmatites, gneisses, crystalline basement rocks) (Badejo, 1975; Wright, 1976; Turner, 1976). According to Badejo (1975), these rocks are host to cassiterite and columbite ores. This explains why these ores have been mined, milled and processed for tin for more than a century in Jos and its environs. Other minerals such as tantalite, xenotime, thorite, monazite and, zirconium are also known to be associated with the geology of Jos (Arogunjo et al., 2009). The mine site under study is active and has been in operation for many years. It is located in residential area and heavy human activities exist in the area. The location map of the study area is shown in Figure 2.

Gamma Radiation Measurement: The measurement of radiation dose rate at an active mine in Du district of Jos south Nigeria was carried out by adopting an in situ measurement approach. The in situ data was collected with a Geiger-Mueller based multipurpose survey meter (RDS-31MIRION) at 62 survey points as indicated in Figure 3. The survey meter is a battery operated digital handheld unit of dimension $100 \times 67$ x $33 \mathrm{~mm}$ and weighs about $175 \mathrm{~g}$. In addition to gamma rays, the detector can also be used to detect alpha and beta particles using appropriate probes. The gamma-ray energy response and dose measurement capacity of the detector range from $48 \mathrm{keV}$ to $3 \mathrm{MeV}$ and $0.01 \mu \mathrm{Sv}$ to $10 \mathrm{~Sv}$ respectively. The calibration of the detector was verified at the National Institute of Radiation Protection and Research situated in the University of Ibadan, Ibadan, Nigeria. The institute is a facility of the Nigerian Nuclear Regulatory Authority (NNRA).

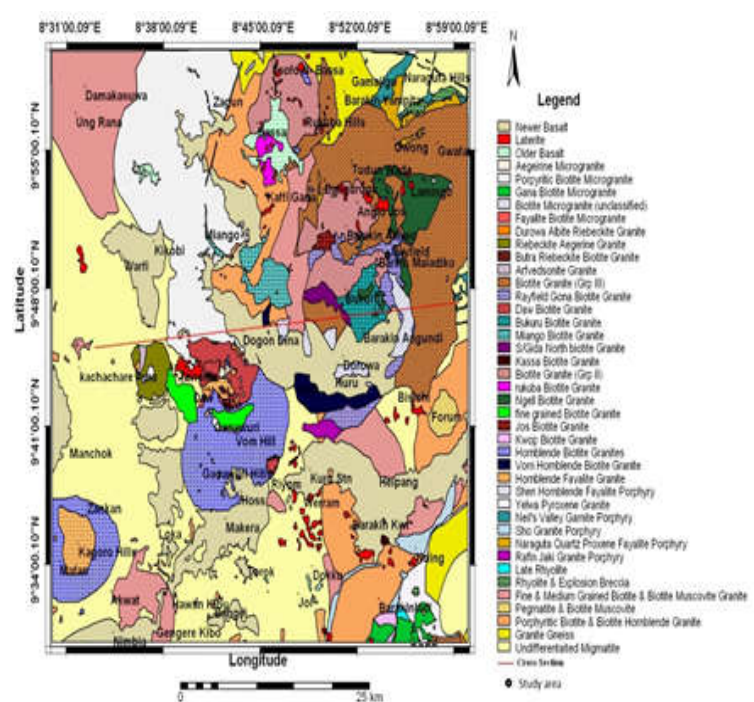

Fig 1: Geological Map of Jos (Naraguta Sheet 168) (Compiled and Published by the

Geological Survey of Nigeria, 1963).

At each measurement point, the survey meter was positioned at $1 \mathrm{~m}$ above the ground level (Agbalagba, 2017; NCRP, 1990) and dose rate measurement was recorded. The elevation above sea level together with the location coordinate of each point were also measured and recorded with a Global Positioning System (GPS) unit (Garmin GPSMAP76CSx). All the measurement locations were distributed across the active and safe areas of the mine. Of all the 62 points of measurement, 42 points were chosen in the processing areas and mine pits. The processing areas contain small heaps of mine tailings scattered across the field and the mining pits are where the mineral soils are collected. The remaining 20 points were in areas where there are no mining activities but used as administrative areas. To ensure the accuracy of collected data, measurements were repeated five times at each of the sampling points and averaged. All measurements were carried out within two months 
(November and December) in the dry season and between 1200 and $1600 \mathrm{hr}$ daily. This is to minimize the effect of soil moisture attenuation of gamma-ray intensity, uniformity of conditions and to avoid random error that could be due to variation in atmospheric parameters (NCRP, 1990).

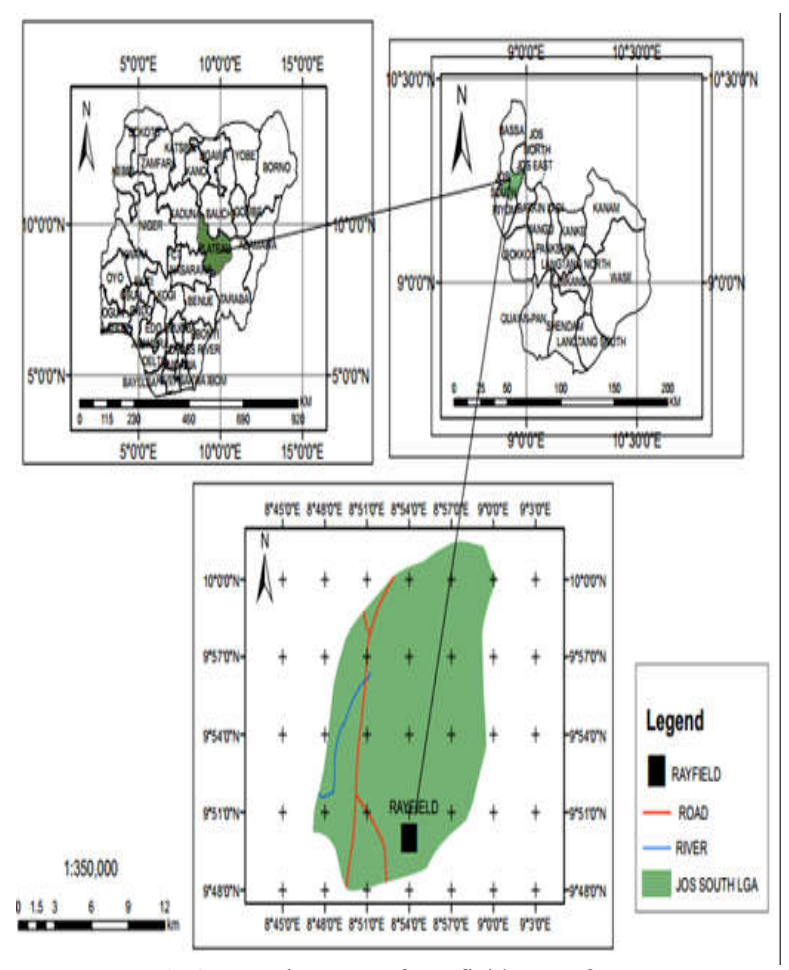

Fig 2. Location map of Rayfield area of Jos

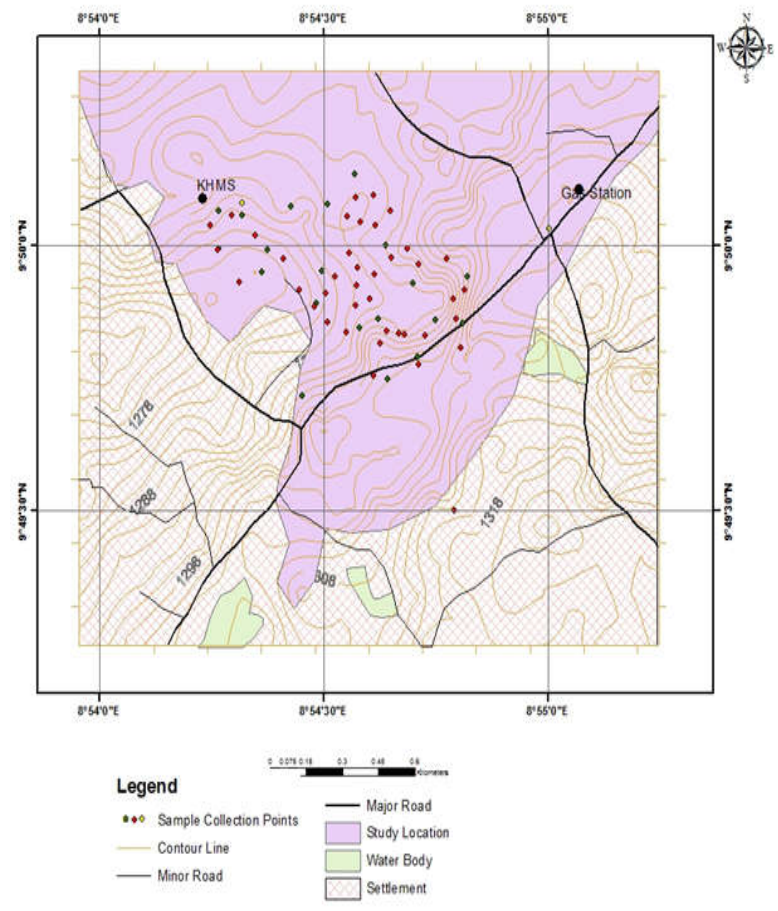

Fig 3. Sampling point at the mine

\section{RESULTS AND DISCUSSION}

The values of the measured absorbed dose rate $(A D R)$ in air at $1 \mathrm{~m}$ above ground level are presented in Table 1 and 2 for both the twenty (20) administrative areas (S) (devoid of mining and processing activities) and the forty-two (42) mining and processing areas (TM) (with tailings, mineral soils and mining pits) respectively. Radiological hazard indices and their analysis are a very important aspects of radiation impact studies. This is necessary in order to arrive at a dependable evaluation of hazards involved in radiation exposure. To assess the radiological risk due to the measured absorbed dose rate - ADR $(\mu \mathrm{Sv} / \mathrm{h})$, the annual effective dose rate (AEDR) and excess lifetime cancer risk factor $(E L C R)$ were evaluated from the values of ADR measured at all the 62 points of interest.

The AEDR $\left(\mathrm{mSvy}^{-1}\right)$ at $1 \mathrm{~m}$ above the ground level in air for external exposure was estimated according to the equation (UNSCEAR, 2000):

$$
A E D R\left(\frac{m S v}{y}\right)=A D R \times 8760 \times 0.2 \times 10^{-3}
$$

Where 8760 is the number of hours in a year and 0.2 is the outdoor occupancy factor and $10^{-3}$ is the conversion factor from $\mu \mathrm{Sv}$ to $\mathrm{mSv}$.

The $E L C R$ for outdoor exposure was evaluated from the AEDR using equation 2 (Agbalagba, 2017).

$$
E L C R=A E D R \times L \times R F
$$

Where $\mathrm{L}$ is the life expectancy taken as (70 yrs) and $\mathrm{RF}$ is the risk factor taken as $(0.05 / \mathrm{Sv})$.

The values of the calculated $A E D R$ and $E L C R$ for the 20 non active mining points (S), and the forty-two (42) mining and processing areas (TM) (with tailings, mineral soils and mining pits) (TM) are also presented in Tables 1 and 2 respectively together with the location coordinates and elevations above sea level. From the results, the ADR values of the administrative areas in Table 1 varied from 0.21 to $0.54 \mu \mathrm{Svh}^{-1}$ with a mean of $0.3845 \mu \mathrm{Svh}^{-1}$. While for the active mining and processing areas, (Table 2), the ADR was between 0.56 to $2.14 \mu \mathrm{Svh}^{-1}$ with a mean value of $1.04 \mu \mathrm{Svh}^{-1}$. For the entire mining site, the average ADR for both soil and tailing points was $0.83 \mu \mathrm{Svh}^{-1}$. The AEDR and ELCR values for the mine area have a total mean values of $1.45 \mu \mathrm{Svy}^{-1}$ and 5.07 respectively. The variations of the AEDR and ELCR were from 0.37 to $3.75 \mu \mathrm{Svy}^{-1}$ and 1.29 to 13.12 respectively. The elevation of the 62 survey points varies from 1256 to $1302 \mathrm{~m}$ with an average value of $1271 \mathrm{~m}$. 
Table 1. Measured ADR, elevation, coordinate and calculated dose parameters of contaminated soil.

\begin{tabular}{|c|c|c|c|c|c|c|}
\hline $\begin{array}{l}\text { Sample } \\
\text { point ID }\end{array}$ & Latitude & Longitude & $\begin{array}{l}\text { Elevation } \\
\text { (m) }\end{array}$ & $\begin{array}{l}\text { ADR } \\
(\mu \mathrm{Sv} / \mathrm{h})\end{array}$ & $\begin{array}{l}\text { AEDR } \\
(\mathrm{mSv} / \mathrm{y}\end{array}$ & $\begin{array}{l}\text { ELCR } \\
\left(\mathrm{X} 10^{-3}\right)\end{array}$ \\
\hline S1 & $9^{\circ} 49^{\prime} 45.2^{\prime \prime} \mathrm{N}$ & $8^{\circ} 54^{\prime} 36.6 " \mathrm{E}$ & 1290 & 0.21 & 0.37 & 1.29 \\
\hline S2 & $9^{\circ} 50^{\prime} 3.3^{\prime \prime} \mathrm{N}$ & $8^{\circ} 54^{\prime} 17.7 " \mathrm{E}$ & 1276 & 0.27 & 0.47 & 1.66 \\
\hline $\mathrm{S} 3$ & $9^{\circ} 50^{\prime} 8^{\prime \prime} \mathrm{N}$ & $8^{\circ} 54^{\prime} 34.2^{\prime \prime} \mathrm{E}$ & 1270 & 0.27 & 0.47 & 1.66 \\
\hline S4 & $9^{\circ} 49^{\prime} 59.5^{\prime \prime} \mathrm{N}$ & $8^{\circ} 54^{\prime} 22.4^{\prime \prime} \mathrm{E}$ & 1280 & 0.27 & 0.47 & 1.66 \\
\hline S5 & $9^{\circ} 50^{\prime} 1.8^{\prime \prime} \mathrm{N}$ & $8^{\circ} 55^{\prime} 0.2^{\prime \prime} \mathrm{E}$ & 1302 & 0.27 & 0.47 & 1.66 \\
\hline S6 & $9^{\circ} 50^{\prime} 4.6^{\prime \prime} \mathrm{N}$ & $8^{\circ} 54^{\prime} 30.5^{\prime \prime} \mathrm{E}$ & 1268 & 0.28 & 0.49 & 1.72 \\
\hline S7 & $9^{\circ} 50^{\prime} 3.4^{\prime \prime} \mathrm{N}$ & $8^{\circ} 54^{\prime} 19^{\prime \prime} \mathrm{E}$ & 1280 & 0.32 & 0.56 & 1.96 \\
\hline $\mathrm{S} 8$ & $9^{\circ} 50^{\prime} 4.7^{\prime \prime} \mathrm{N}$ & $8^{\circ} 54^{\prime} 19^{\prime \prime} \mathrm{E}$ & 1280 & 0.32 & 0.56 & 1.96 \\
\hline S9 & $9^{\circ} 50^{\prime} 4.4^{\prime \prime} \mathrm{N}$ & $8^{\circ} 54^{\prime} 25.6^{\prime \prime} \mathrm{E}$ & 1279 & 0.33 & 0.58 & 2.02 \\
\hline $\mathrm{S} 10$ & $9^{\circ} 50^{\prime} 3.2^{\prime \prime} \mathrm{N}$ & $8^{\circ} 54^{\prime} 33.1^{\prime \prime E}$ & 1259 & 0.36 & 0.63 & 2.21 \\
\hline S11 & $9^{\circ} 50^{\prime} 3.8^{\prime \prime} \mathrm{N}$ & $8^{\circ} 54^{\prime} 95.9 " \mathrm{E}$ & 1278 & 0.38 & 0.67 & 2.33 \\
\hline $\mathrm{S} 12$ & $9^{\circ} 49^{\prime} 48.4^{\prime \prime} \mathrm{N}$ & $8^{\circ} 54^{\prime} 48.3^{\prime \prime} \mathrm{E}$ & 1299 & 0.39 & 0.68 & 2.39 \\
\hline $\mathrm{S} 13$ & $9^{\circ} 49^{\prime} 43^{\prime \prime N}$ & $8^{\circ} 54^{\prime} 27.1 " \mathrm{E}$ & 1287 & 0.45 & 0.79 & 2.76 \\
\hline S14 & $9^{\circ} 50^{\prime} 1.1 " \mathrm{~N}$ & $8^{\circ} 54^{\prime} 20.8^{\prime \prime} \mathrm{E}$ & 1271 & 0.46 & 0.81 & 2.82 \\
\hline S15 & $9^{\circ} 50^{\prime} 5.3^{\prime \prime} \mathrm{N}$ & $8^{\circ} 54^{\prime} 34.3^{\prime \prime} \mathrm{E}$ & 1263 & 0.47 & 0.82 & 2.88 \\
\hline S16 & $9^{\circ} 49^{\prime} 56.4^{\prime \prime} \mathrm{N}$ & $8^{\circ} 54^{\prime} 49.2 " \mathrm{E}$ & 1278 & 0.48 & 0.84 & 2.94 \\
\hline S17 & $9^{\circ} 49^{\prime} 50.2^{\prime \prime} \mathrm{N}$ & $8^{\circ} 54^{\prime} 33^{\prime \prime} \mathrm{E}$ & 1269 & 0.54 & 0.95 & 3.31 \\
\hline S18 & $9^{\circ} 50^{\prime} 2.2^{\prime \prime} \mathrm{N}$ & $8^{\circ} 54^{\prime} 14.8^{\prime \prime} \mathrm{E}$ & 1271 & 0.54 & 0.95 & 3.31 \\
\hline S19 & $9^{\circ} 49^{\prime} 51.1 " \mathrm{~N}$ & $8^{\circ} 54^{\prime} 48.6 " \mathrm{E}$ & 1279 & 0.54 & 0.95 & 3.31 \\
\hline S20 & $9^{\circ} 49^{\prime} 51.7^{\prime \prime} \mathrm{N}$ & $8^{\circ} 54^{\prime} 37.3 " \mathrm{E}$ & 1261 & 0.54 & 0.95 & 3.31 \\
\hline
\end{tabular}

The spatial distribution of the elevation, ADR, AEDR, and ELCR for the mine are depicted in Figures 4a-d. From the figures, a strong correlation between ADR, AEDR, and ELCR could be observed as expected from the computation expressions (equations 1 and 2). However, area with higher ADR, AEDR, and ELCR can be observed to correspond to lower elevation points. Consequently, there is an inverse correlation between ADR, AEDR, and ELCR; and elevation above sea level. Places with low values of elevation mostly correspond to places on the minefield where mine pits have been dug for the collection of unprocessed soil and rock for mining and milling. The dug pits also have in some cases heaps of both process (tailings) and unprocessed rocks and soils. These tailings and mineral soils are rich in NORM which produces radiation as they decay. This explains the elevated values of measured absorbed dose in these areas. The high $A D R$ areas are located around the North-Western part of the mine Figure $4 \mathrm{~b}$. Another feature that can be attributed to the high $A D R$ is the mining pits is the fact that excavation exposes mineral and radionuclide rich rock which could have been attenuated by surface soils. The exposure of such rocks and their radiation and radionuclide bearing minerals such as monazite contributed to the higher $A D R$ values measured at those places. Generally, the measured radiation level of administrative areas was lower compared to places where mining and processing were taking place. Tailings and mineral soils have been proven to contain a high level of primordial radionuclide and thus gamma radiation doses (Ademola, 2008; Ibeanu, 2003; Arogunjo et al., 2009; Abba et al., 2018). This automatically accounts for the observed higher dose rates in air. The mean measured $A D R, A E D R$, and $E L C R$ for the mine were all higher than their corresponding world average according to (UNSCEAR, 2000) and safety limit according to the ICRP (1990). The mean measured $A D R$ value of 0.83 $\mu \mathrm{Svh}^{-1}$ was about 17 times greater than the world average value of $0.05 \mu \mathrm{Svh}^{-1}$. On the hand, the mean AEDR of $1.44 \mathrm{mSvy}^{-1}$ was 24 times greater than the outdoor world average value of $0.07 \mathrm{mSvy}^{-1}$ (UNSCEAR, 2000). Compared to the occupational and public exposure limit of $1.5 \mathrm{mSvy}^{-1}$ and $1.0 \mathrm{mSvy}^{-}$ ${ }^{1}$ respectively recommended by the ICRP (1990), the average computed $A E D R$ was relatively higher for public exposure and almost equal to that of the occupational exposure. The average calculated $E L C R$ value for the mine $\left(5.07 \times 10^{-3}\right)$ was extremely higher than the world average value of $0.29 \times 10^{-3}$ (UNSCEAR, 2000). This implies that anyone (miners, dwellers, and others) staying or working in the minefield has more chances of developing cancer mine more than anywhere else in the world by a father of about 17 if they spent all their lives around the mine and live up to 70 years old. The geology (Olarinoye et al., 2010) of the mine area (Jos), and the presence of mineral ores of columbite, tin, monazite, and other NORM rich minerals are majorly responsible for the relatively high measured and calculated radiological parameters in the mine area. 
High Terrestrial Radiation Level in an Active.....

Table 2. Measured ADR, elevation, coordinate and calculated dose parameters in tailing areas

\begin{tabular}{|c|c|c|c|c|c|c|}
\hline $\begin{array}{l}\text { Sample } \\
\text { point ID }\end{array}$ & Latitude & Longitude & $\begin{array}{l}\text { Elevation } \\
\text { (m) }\end{array}$ & $\begin{array}{l}\text { ADR } \\
(\mu \mathrm{Sv} / \mathrm{h})\end{array}$ & $\begin{array}{l}\begin{array}{l}\text { AEDR } \\
(\mathrm{mSv} / \mathrm{y}\end{array} \\
\end{array}$ & $\begin{array}{l}\text { ELCR } \\
\left(10^{-3}\right)\end{array}$ \\
\hline TM1 & $9^{\circ} 49^{\prime} 48.9^{\prime \prime} \mathrm{N}$ & $8^{\circ} 54^{\prime} 37.5^{\prime \prime} \mathrm{E}$ & 1265 & 0.56 & 0.98 & 3.43 \\
\hline TM2 & $9^{\circ} 49^{\prime} 51.3^{\prime \prime} \mathrm{N}$ & $8^{\circ} 54^{\prime} 30.5^{\prime \prime} \mathrm{E}$ & 1265 & 0.58 & 1.02 & 3.56 \\
\hline TM3 & $9^{\circ} 49^{\prime} 57.1 " \mathrm{~N}$ & $8^{\circ} 54^{\prime} 29.7 " \mathrm{E}$ & 1261 & 0.58 & 1.02 & 3.56 \\
\hline TM4 & $9^{\circ} 49^{\prime} 59.6 " \mathrm{~N}$ & $8^{\circ} 54^{\prime} 15.9^{\prime \prime E}$ & 1269 & 0.61 & 1.07 & 3.74 \\
\hline TM5 & $9^{\circ} 50^{\prime} 5.6 " \mathrm{~N}$ & $8^{\circ} 54^{\prime} 36.6^{\prime \prime E}$ & 1263 & 0.64 & 1.12 & 3.92 \\
\hline TM6 & $9^{\circ} 49^{\prime} 50.6 " \mathrm{~N}$ & $8^{\circ} 54^{\prime} 34.8^{\prime \prime} \mathrm{E}$ & 1272 & 0.64 & 1.12 & 3.92 \\
\hline TM7 & $9^{\circ} 49^{\prime} 58.5^{\prime \prime} \mathrm{N}$ & $8^{\circ} 54^{\prime} 24.6 " \mathrm{E}$ & 1275 & 0.65 & 1.14 & 3.99 \\
\hline TM8 & $9^{\circ} 50^{\prime} 2.2^{\prime \prime} \mathrm{N}$ & $8^{\circ} 54^{\prime} 36.9^{\prime \prime} \mathrm{E}$ & 1263 & 0.68 & 1.19 & 4.17 \\
\hline TM9 & $9^{\circ} 49^{\prime} 54.9^{\prime \prime} \mathrm{N}$ & $8^{\circ} 54^{\prime} 48.8^{\prime \prime} \mathrm{E}$ & 1276 & 0.68 & 1.19 & 4.17 \\
\hline TM10 & $9^{\circ} 49^{\prime} 44.9^{\prime \prime} \mathrm{N}$ & $8^{\circ} 54^{\prime} 38.6 " \mathrm{E}$ & 1271 & 0.69 & 1.21 & 4.23 \\
\hline T M11 & $9^{\circ} 50^{\prime} 2.6 " \mathrm{~N}$ & $8^{\circ} 54^{\prime} 34.9 " \mathrm{E}$ & 1259 & 0.7 & 1.23 & 4.29 \\
\hline TM12 & $9^{\circ} 49^{\prime} 49.9^{\prime \prime} \mathrm{N}$ & $8^{\circ} 54^{\prime} 40.8^{\prime \prime} \mathrm{E}$ & 1280 & 0.71 & 1.24 & 4.35 \\
\hline TM13 & $9^{\circ} 49^{\prime} 50.3^{\prime \prime} \mathrm{N}$ & $8^{\circ} 54^{\prime} 38.4^{\prime \prime} \mathrm{E}$ & 1263 & 0.73 & 1.28 & 4.48 \\
\hline TM14 & $9^{\circ} 49^{\prime} 53.4^{\prime \prime} \mathrm{N}$ & $8^{\circ} 54 ' 29 " \mathrm{E}$ & 1267 & 0.74 & 1.30 & 4.54 \\
\hline TM15 & $9^{\circ} 49^{\prime} 51.5^{\prime \prime} \mathrm{N}$ & $8^{\circ} 54^{\prime} 45^{\prime \prime} \mathrm{E}$ & 1277 & 0.79 & 1.38 & 4.84 \\
\hline TM16 & $9^{\circ} 49^{\prime} 53.9^{\prime \prime} \mathrm{N}$ & $8^{\circ} 54^{\prime} 36.1 " \mathrm{E}$ & 1259 & 0.8 & 1.40 & 4.91 \\
\hline TM17 & $9^{\circ} 49^{\prime} 56.4^{\prime \prime} \mathrm{N}$ & $8^{\circ} 54^{\prime} 31.5^{\prime \prime} \mathrm{E}$ & 1261 & 0.81 & 1.42 & 4.97 \\
\hline TM18 & $9^{\circ} 49^{\prime} 55.7^{\prime \prime} \mathrm{N}$ & $8^{\circ} 54^{\prime} 41.9^{\prime \prime} \mathrm{E}$ & 1267 & 0.87 & 1.52 & 5.33 \\
\hline TM19 & $9^{\circ} 50^{\prime} 3.9^{\prime \prime} \mathrm{N}$ & $8^{\circ} 54^{\prime} 38.9^{\prime \prime} \mathrm{E}$ & 1262 & 0.88 & 1.54 & 5.40 \\
\hline TM20 & $9^{\circ} 49^{\prime} 54.5^{\prime \prime} \mathrm{N}$ & $8^{\circ} 54^{\prime} 30.3^{\prime \prime E}$ & 1261 & 0.9 & 1.58 & 5.52 \\
\hline TM21 & $9^{\circ} 49^{\prime} 59.6^{\prime \prime} \mathrm{N}$ & $8^{\circ} 54^{\prime} 41.2^{\prime \prime} \mathrm{E}$ & 1266 & 0.92 & 1.61 & 5.64 \\
\hline TM22 & $9^{\circ} 49^{\prime} 59.1 " \mathrm{~N}$ & $8^{\circ} 54^{\prime} 33.4^{\prime \prime} \mathrm{E}$ & 1262 & 0.94 & 1.65 & 5.76 \\
\hline TM23 & $9^{\circ} 49^{\prime} 30.1^{\prime \prime} \mathrm{N}$ & $8^{\circ} 54^{\prime} 47.4^{\prime \prime} \mathrm{E}$ & 1280 & 0.96 & 1.68 & 5.89 \\
\hline TM24 & $9^{\circ} 49^{\prime} 57.4^{\prime \prime} \mathrm{N}$ & $8^{\circ} 54^{\prime} 34.5^{\prime \prime} \mathrm{E}$ & 1256 & 0.98 & 1.72 & 6.01 \\
\hline TM25 & $9^{\circ} 49^{\prime} 58.6^{\prime \prime} \mathrm{N}$ & $8^{\circ} 54^{\prime} 39^{\prime \prime} \mathrm{E}$ & 1267 & 1 & 1.75 & 6.13 \\
\hline TM26 & $9^{\circ} 49^{\prime} 51.7 " \mathrm{~N}$ & $8^{\circ} 54^{\prime} 47.7^{\prime \prime E}$ & 1278 & 1.03 & 1.80 & 6.32 \\
\hline TM27 & $9^{\circ} 49^{\prime} 56.9^{\prime \prime} \mathrm{N}$ & $8^{\circ} 54^{\prime} 21.7 " \mathrm{E}$ & 1264 & 1.03 & 1.80 & 6.32 \\
\hline TM28 & $9^{\circ} 50^{\prime} 0 " \mathrm{~N}$ & $8^{\circ} 54^{\prime} 38.3^{\prime \prime E}$ & 1266 & 1.03 & 1.80 & 6.32 \\
\hline TM29 & $9^{\circ} 49^{\prime} 46.5^{\prime \prime} \mathrm{N}$ & $8^{\circ} 54^{\prime} 42.7 " \mathrm{E}$ & 1287 & 1.04 & 1.82 & 6.38 \\
\hline TM30 & $9^{\circ} 49^{\prime} 47.4^{\prime \prime} \mathrm{N}$ & $8^{\circ} 54^{\prime} 42.6^{\prime \prime} \mathrm{E}$ & 1270 & 1.05 & 1.84 & 6.44 \\
\hline TM31 & $9^{\circ} 49^{\prime} 53 " \mathrm{~N}$ & $8^{\circ} 54^{\prime 2} 28.7 " \mathrm{E}$ & 1263 & 1.06 & 1.86 & 6.50 \\
\hline TM32 & $9^{\circ} 49^{\prime} 53.9^{\prime \prime} \mathrm{N}$ & $8^{\circ} 54^{\prime} 47.3^{\prime \prime} \mathrm{E}$ & 1273 & 1.14 & 2.00 & 6.99 \\
\hline TM33 & $9^{\circ} 49^{\prime} 59.4^{\prime \prime} \mathrm{N}$ & $8^{\circ} 54^{\prime} 15.8^{\prime \prime} \mathrm{E}$ & 1268 & 1.41 & 2.47 & 8.65 \\
\hline TM34 & $9^{\circ} 49^{\prime} 50^{\prime \prime} \mathrm{N}$ & $8^{\circ} 54^{\prime} 40 " \mathrm{E}$ & 1282 & 1.44 & 2.52 & 8.83 \\
\hline TM35 & $9^{\circ} 49^{\prime} 55.8^{\prime \prime} \mathrm{N}$ & $8^{\circ} 54^{\prime} 18.7 " \mathrm{E}$ & 1264 & 1.49 & 2.61 & 9.14 \\
\hline TM36 & $9^{\circ} 49^{\prime} 49.8^{\prime \prime} \mathrm{N}$ & $8^{\circ} 54^{\prime} 43.6 " \mathrm{E}$ & 1281 & 1.68 & 2.94 & 10.30 \\
\hline TM37 & $9^{\circ} 49^{\prime} 58.4^{\prime \prime} \mathrm{N}$ & $8^{\circ} 54^{\prime} 46.5^{\prime \prime} \mathrm{E}$ & 1271 & 1.7 & 2.98 & 10.42 \\
\hline TM38 & $9^{\circ} 49^{\prime} 53.2^{\prime \prime} \mathrm{N}$ & $8^{\circ} 54^{\prime} 34.3^{\prime \prime} \mathrm{E}$ & 1257 & 1.71 & 3.00 & 10.49 \\
\hline TM39 & $9^{\circ} 49^{\prime} 55.4^{\prime \prime} \mathrm{N}$ & $8^{\circ} 54^{\prime} 34.4^{\prime \prime} \mathrm{E}$ & 1257 & 1.75 & 3.07 & 10.73 \\
\hline TM40 & $9^{\circ} 49^{\prime} 54.9^{\prime \prime} \mathrm{N}$ & $8^{\circ} 54^{\prime} 26.7^{\prime \prime E}$ & 1276 & 1.9 & 3.33 & 11.65 \\
\hline TM41 & $9^{\circ} 49^{\prime} 56.7^{\prime \prime} \mathrm{N}$ & $8^{\circ} 54^{\prime} 36.8^{\prime \prime} \mathrm{E}$ & 1262 & 1.93 & 3.38 & 11.83 \\
\hline TM42 & $9^{\circ} 49^{\prime} 57.8^{\prime \prime} \mathrm{N}$ & $8^{\circ} 54^{\prime} 42.7^{\prime \prime} \mathrm{E}$ & 1269 & 2.14 & 3.75 & 13.12 \\
\hline
\end{tabular}

The higher values of $A D R$ and other radiological safety parameters in TM compared to $\mathrm{S}$ areas could also be attributed to their richer mineral content which have been reduced due to mining processes or attenuated by surface soils in the $\mathrm{S}$ areas. Effective doses received by the different organs $\left(D_{o}\right)$ of the people living or working in the mine was estimated from the annual effective dose rate $(A E D R)$ according to the equation 3 (Ibeanu, 2003):

$D_{o}\left(m S v y^{-1}\right)=O F \times A E D R\left(m S v y^{-1}\right) \times F$

Where $O F$ is the occupancy factor $(0.2)$, and $\mathrm{F}$ is the organ of interest (and their corresponding organ conversion factor) include lungs (0.64), ovaries (0.58), 
bone marrow (0.69), testes (0.82), kidney (0.62), and liver (0.46) (ICRP, 1996).

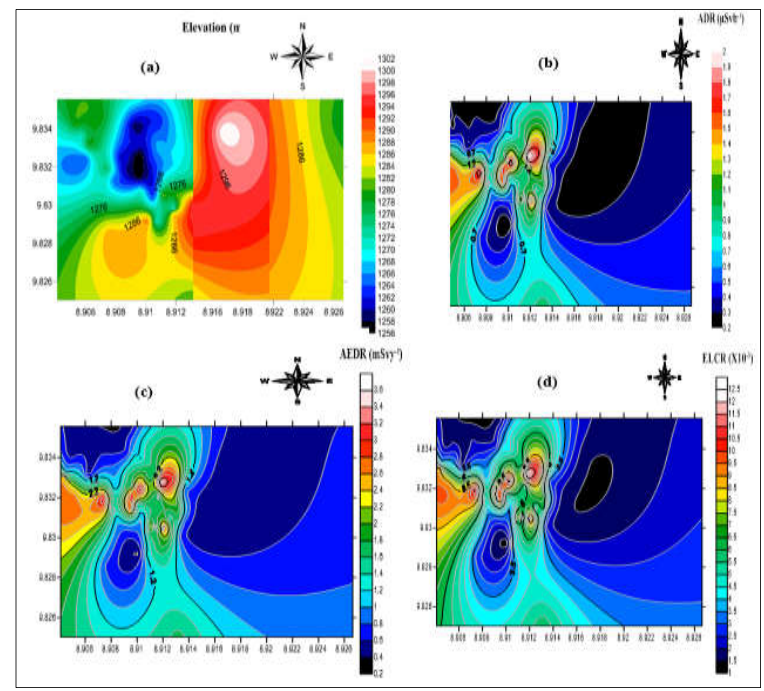

Fig 4. Spatial distribution of (a) Elevation, (b) ADR, (c) ELCR, (d) AEDR across the mine.
Equation 3 estimate the $D_{o}$ as the amount of radiation intake by a person that enters and get accumulated in the different organs of the human body. The values of the organs doses of the six different human organs of interest calculated via equation 3 is presented in Table 3 . from the results, the values of the organ doses in the contaminated soil gave generally lower than those obtained from tailing points. Of all the organs considered, the testicles received the highest organ dose value of $0.3 \mathrm{mSvy}^{-1}$ and $0.11 \mathrm{mSvy}^{-1}$ for TM areas and $\mathrm{S}$ areas respectively. While the lowest dose was fond in liver with a value of 0.06 and $0.17 \mathrm{mSvy}^{-}$ ${ }^{1}$ for soil and tailing respectively. The total organ doses values for both $\mathrm{S}$ and TM areas varies from 0.047 to $0.061 \mathrm{mSvy}^{-1}$. The variation in the organ doses is attributed only to their different organ conversion factors $(F)$ values. The organ conversion factor or an organ is a measure of the radio-sensitivity of the organ. Thus high $F$ value for an organ is an indication that the organ has relatively higher risk of radiation damage compare to those organs of lower $F$ value.

Table 3. Summary of measured in-situ ADR, AEDR, ELCR and effective organ doses

\begin{tabular}{|c|c|c|c|c|c|c|c|c|c|c|}
\hline \multirow{2}{*}{$\begin{array}{l}\text { Location } \\
\text { Description }\end{array}$} & \multirow{2}{*}{$\begin{array}{l}\text { Number of } \\
\text { Locations }\end{array}$} & \multirow{2}{*}{$\begin{array}{l}\text { ADR } \\
(\mu \mathrm{Sv} / \mathrm{h})\end{array}$} & \multirow{2}{*}{$\begin{array}{l}\text { AEDR } \\
(\mathrm{mSv} / \mathrm{y})\end{array}$} & \multirow{2}{*}{$\begin{array}{l}\text { ELCR } \\
\left(10^{-3}\right)\end{array}$} & \multicolumn{6}{|c|}{ Mean organ Effective Dose (mSv/y) } \\
\hline & & & & & Lungs & Ovaries & $\begin{array}{l}\text { Bone } \\
\text { marrow }\end{array}$ & Testes & Kidney & Liver \\
\hline TM & 42 & 1.04 & 1.81 & 6.36 & 0.09 & 0.08 & 0.09 & 0.11 & 0.08 & 0.06 \\
\hline $\mathrm{S}$ & 20 & 0.38 & 0.67 & 2.36 & 0.23 & 0.21 & 0.25 & 0.29 & 0.23 & 0.17 \\
\hline Total & 62 & 0.83 & 1.45 & 5.10 & 0.19 & 0.17 & 0.2 & 0.24 & 0.18 & 0.1 \\
\hline \multicolumn{2}{|l|}{ Minimum } & 0.21 & 0.37 & 1.29 & 0.05 & 0.04 & 0.05 & 0.06 & 0.04 & 0.03 \\
\hline \multicolumn{2}{|l|}{ Maximum } & 2.14 & 3.75 & 13.12 & 0.48 & 0.43 & 0.52 & 0.61 & 0.46 & 0.34 \\
\hline \multicolumn{2}{|c|}{ World mean value* } & 0.05 & 0.07 & 0.29 & & & & & & \\
\hline \multicolumn{2}{|c|}{ Safety limit** } & & 1 & & & & & & & \\
\hline
\end{tabular}

Table 4. Comparison of ADR with earlier research in other places

\begin{tabular}{llll}
\hline Location & Location description & $\begin{array}{l}\text { In-situ ADR } \\
(\mu \mathrm{Sv} / \mathrm{h})\end{array}$ & Reference \\
& & $5-80$ & Funta and Elegba, 2005 \\
\hline Bukuru, Nigeria & Tine Mine & $6-28$ & Ademola, 2008 \\
Jos, Nigeria & Tine Mine & $0.02-11$ & Ademola et al., 2015 \\
Ede, Nigeria & Columbite, Tantalite, Mine & $0.04-0.12$ & Faanu et al., 2016 \\
Perseus, Ghana & Gold, Mine & $0.07-1.44$ & Ramli, et al., 2015 \\
Johor, Malaysia & High radiation area & $0.21-2.14$ & This study \\
Rayfield Du, Jos, Nigeria & Tin Mine & & \\
\hline
\end{tabular}

The summary of the measured $A D R$ and the calculated radiation safety parameters for the $\mathrm{S}$ and TM areas with respect to safety limits and world average values are also shown in Table 4. The comparison of the $A D R$ measured in this research and other mining areas in Nigeria, Ghana and those of high background area in Malaysia is presented in Table 4 from the tables, the range of $A D R$ obtained in this research though higher than the world average value and safety limits, it was however lower than the values obtained at mining sites in Bukuru, Jos area and Ede all in Nigeria. Ademola (2008) though obtained higher values for Jos where the present research was conducted, however, the coordinates of the area investigated were not given.
Thus it was difficult to evaluate the proximity of the surveyed mine to the presented one. It is most likely that the mine data reported by Ademola (2008) is different from the one under study since there are so many local artisan mines scattered all over Jos and its environment. Furthermore, there has not been any report of mine reclamation, rehabilitation, and restoration practice in the area. It is thus most unlikely that the same mine area with previously elevated values $A D R$ now have lesser values. The result presented here has further buttressed the fact that mining, in no small measure contribute to the terrestrial gamma radiation of an area. Furthermore, it has demonstrated that Jos and environs can be 
classified as high background radiation area in Nigeria. This is true as research had revealed that specific activities of natural radionuclides levels in Jos Plateau tin mines, exceed the mean values for areas designated as high background natural radiation areas (Arogunjo, 2009; Ramli et al., 2015; Amaral et al., 1992; Marsden, 1960). The difference between ADR in this research and those obtained in Malaysia, Ghana and Ede could be attributed to variation in geological and chemical composition of the different areas.

Conclusion: The gamma-radiation level in the mine was higher for areas in the mine which contain tailing heaps and in the mine pits where mineral sands are collected for milling. The evaluated radiation safety indices for the mine were above world average values and safety limits. The potential of developing radiation-induced sicknesses due to high radiation absorbed dose by the miners and dwellers around the mine is very high. As a matter of urgency, regulatory authority need to commence activities geared toward the process of reclamation, rehabilitation and imposing regulations on the mine and its environment.

\section{REFERENCES}

Abba, HT; Hassan, WM; Saleh, MA (2018). Evaluation of environmental natural radioactivity levels in soils and ground water of Baarkin Ladi, Plateau state Nigeria. Malaysian Journal of Fundamental and Applied Science, 14 (3), 338342 .

Ademola, JA (2008). Exposure to high background radiation level in the tin mining area of Jos, Plateau, Nigeria. Journal of Radiation Protection 28: $93-99$.

Adewale, OO; Tubosun, IA; Go, JO. (2015). Assessment of Terrestrial Naturally occurring radioactive material in soil and mine tailings of Awo and Ede, Osun - state, Nigeria. Ife Journal of Science 17 (1), 199 - 209.

Agbalagba, OE (2017). Assessment of excess lifetime cancer risk from gamma radiation levels in Effurun and Warri of Delta state, Nigeria. Journal of Taibah University for Science, 11(3), 367-380.

Amaral, EC; Rochedo, ER; Paretzke, HG; Franca, EP (1992). The radiological impact of agricultural activities in an area of high natural radioactivity. Radiation Protection Dosimetry 45, 289-292.

Arogunjo, AM; Hollriegl, V; Giussani, A; Leopeld, K; Gerstmann, U; Veronese, I; Oeh, U (2009). Uranium and thorium in soils, minerals sands water and food samples in a tin mining area in Nigeria with elevated activity. Journal of Environmental Radioactivity 100: (232-240).

Badejo, TA (1975). Evidence of magmatic differentiation in the origin of the younger granites of Nigeria Journal of. Mining Geol. 10, 67.

Faanu, A; Adukpo, OK; Tettey-Larbi, L; Lawluvi, H; Kpeglo, DO; Darko, EO; Emi-Reynolds, G; Awudu, RA. (2016). Natural radioactivity level in soils, rocks, and water at a mining concessionof Perseus gold mine and surrounding towns in central Region of Ghana. springerPlus, 5:98, 1-16

Funtua, II; Elegba, SB (2005). Radiation Exposure from High-level radiation area and related mining and processing activities of Jos Plateau, central Nigeria.

Ibeanu, I (2003). Tin mining and processing in Nigeria: cause for concern. Journal of Environmental Radioactivity 64 (2003) 59-66.

ICRP (1996). Recommendations of the International Commission on Radiological Protection, Publication 73-Radiological Protection and Safety in Medicine. Pergamon Press, Oxford.

ICRP. (1990). Recommendations of the International Commission on Radiological Protection, ICRP Publication 60, Pergamon Press, Oxford.

Jibiri, NN; Farai, IP; Alausa, SK (2007). Estimation of annual effective dose due to natural radioactive elements in ingestion of foodstuffs in tin mining area of Jos-Plateau, Nigeria. Journal of Environmental Radioactive. (94) 31-40.

Jwanbot, DI; Izam, MM; Gambo, M (2012). Measurement of Indoor Background Ionizing Radiation in Some Science Laboratories in University of Jos, Jos - Nigeria; Science World Journal 7 (2). 5-8.

Marsden, E (1960). Radioactivity of soils, plants and bones. Nature 187, 192-195.

Masok, FB; Ike-Ogbonna, MI; Dawam, RB; Jwanbot, DI; Yenle, NM (2015). Cancer risk due to radionuclide Concentration in tin Ore and sediments at Barkin-Ladi, Plateau State, North Central, Nigeria. International Journal of Environmental Monitoring and Analysis 3(5), 260-64. 
NCRP. National Council on Radiation Protection and Measurement (1990). Limitation of ionizing radiation exposure. NCRP report No. 116.

NGSA. Geological Survey of Nigeria (1963). Geology map of Naraguta, sheet 168.

Olarinoye, I.O.; Sharifat, I.; Baba-Kutigi, A, N.; Kolo, and M.T.; Aladeniyi, K. (2010). Measurement of Background Gamma Radiation Levels at Two Tertiary Institutions in Minna, Nigeria. J. Appl. Sci. Environ. Manage, 14 (1) $59-62$.

Olise FS; Oladejo O.F; Almeida, SM; Owoade, OK; Olaniyi, HB; Freitas MC (2014). Instrument neutron activation analyses of uranium and thorium in samples from tin mining and processing sites. J. Geochem. Explur. 142, 36-42.

Ramli, AT; Wahab, A; Hussein, MA; Wood, AK (2015). Environmental ${ }^{238} \mathrm{U}$ and ${ }^{232} \mathrm{Th}$ concentration measurements in an area of high level natural background radiation at Palong, Jahor, Malaysia. Journal of Environmental Radioactivity, 80, 287-304.
Turner, DC (1976). "'Structure and Petrology of the Younger Granite Ring Complexes of Nigeria.' In Geology of Nigeria edited by Kogbe, C.A. Lagos Nigeria: Elizabethan Publication Company, Lagos Nigeria.

UNSCEAR. United Nations Scientific Committee on the Effects of Atomic Radiation (2000). Sources and effects of ionizing radiation. UNSCEAR Report to General Assembly, United Nations, New York.

Usikalu, MR; Anoka, OC; Balogun, FA (2011). Radioactivity measurements of the Jos tin mine tailing in Northern Nigeria Archives of Physics Research 2(2). 80-86.

Wapwera, SD Ayanbimpe, GN; Odita, CE (2005). Abandoned mne, potential home for the people: A case study of Jos Plateau tin - Mining Region. Journal of Civil Engineering and Architecture 9, $429-445$.

Wright, JB (196). A Critical Review of the Geology of Nigeria. Edited by Kogbe, CA Elizabethan Publisher Company, Lagos Nigeria, PP309 - 317. 